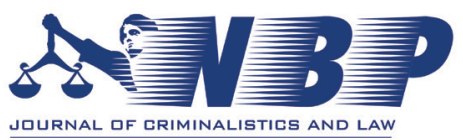

NBP 2021, Vol. 26, Issue 2, pp. 19-30

https://doi.org/10.5937/nabepo26-34101

Original scientific paper

\title{
The Duty to Protect the Right to Life
}

\section{Tijana Šurlan ${ }^{1}$}

University of Criminal Investigation and Police Studies, Belgrade, Serbia

Constitutional Court of the Republic of Serbia, Belgrade, Serbia

Submitted: 2021-09-23 • Accepted: 2021-10-05 • Published: 2021-10-19

Abstract: The author analyses one aspect of the right to life - the duty to protect the right to life. That aspect is not encompassed in definitions of the right to life in clear and explicit words. However, it is elucidated through the process of interpretation by various bodies, both international and national. Explicit inclusion of this element is thoroughly analysed in General Comment No. 36 adopted by the UN Human Rights Committee and it presents the starting point for the analyses in this paper. The duty to protect the right to life has also been elaborated in specific cases before the UN Human Rights Committee, the European Court of Human Rights and constitutional courts. Several of these cases have also been analysed within this paper. The aim of the paper is to identify the scope and limits of the duty to protect the right to life.

Keywords: the right to life, the duty to protect, UN Human Rights Committee, the European Court of Human Rights, constitutional courts.

\section{Graphical abstract}

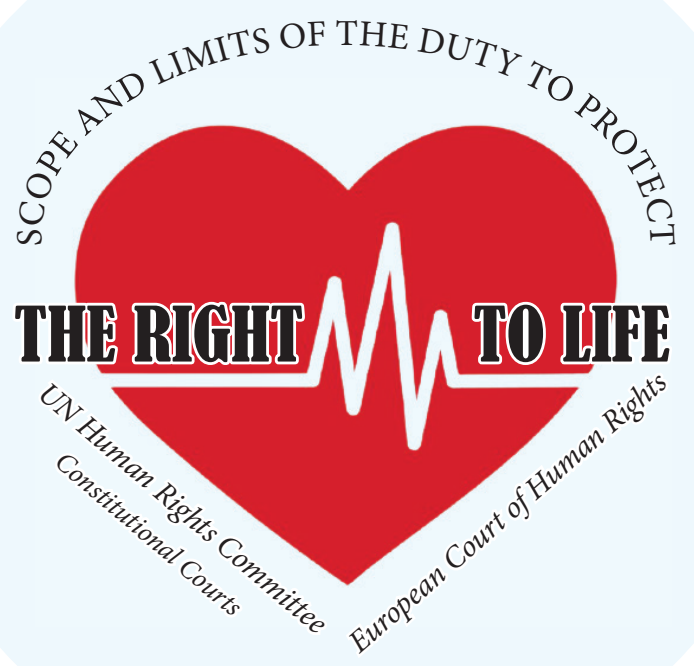

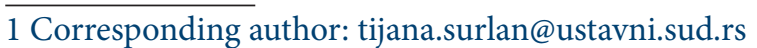




\section{INTRODUCTION}

The right to life undoubtedly is one of the most essential human rights, as well as one of the oldest human rights, the one that had emerged in the dawn of human rights protection (Tomuschat, 2010; Kalin \& Kunzli, 2019). It was born in the process of creation of a modern state, shaped during the liberation and bourgeois revolutions, defined in constitutions from the very emergence of constitutions as the new kind of a legal act, and finally defined in international law documents. The right to life has been applied and interpreted before constitutional courts, international criminal courts, and international human rights courts as well as before the UN Human Rights Committee (HRC).

After such introductory remarks, which are unquestionable, one can ask whether there are still any unknown aspects of the right to life or whether there is still the need to produce yet another article on this right. The issue of novelty, generally, could be grounded in the field of the legal interpretation of a rule, presented in a specific judgment delivered on a specific, awkward set of facts. Yet novelty regarding the right to life rests on a specific new reading of the right to life, presented in the General Comment No. 36 on Article 6 of the International Covenant on Civil and Political Rights, adopted by the Human Rights Committee at the end of the 2018 (UN Human Rights Committee [UNHRC], 2018). This comment varies from the usual mode of drafting general comments; it is comprehensive, exhaustive, it anticipates new trends and interpretations. It is worthy to mention as well, that it was deliberated during the period of four years and finally delivered within 70 paragraphs. Previous comments on Article 6 - the right to life were adopted in 1982 - General Comment no. 6 (UNHRC, 1982) and the second one was adopted in 1984 - General Comment no. 14 (UNHRC, 1984). General Comment 6 was typical of the HRC's earlier general comments, in that it was very short and "added little beyond the obvious to the actual text of the right” (Joseph, 2019: 350). General Comment no. 14 was also a short document, consisting of seven brief paragraphs, aiming to develop specifically the aspect of waging of war and the possession of nuclear weapons. The new General Comment no. 36 replaces the previous general comments, as it is stated at the very beginning of the document, in paragraph 1.

One aspect of this multifaceted right, specifically interesting and very important is the aspect of the duty to protect the right to life. While the definition of the right to life, expressed in every international legal document, does not contain expressly the wording of the duty to protect the life, General Comment No. 36 dedicates one part of the document exquisitely to that aspect of the right to life. The same aspect has been deliberated by the European Court of Human Rights, as well as before various constitutional courts. From that point of view, it becomes clearer that there is need to analyse the scope of the duty to protect the right to life, as well as its limits.

It is interesting and rather necessary to compare the present approach of international and national institutions for protection of the right to life with the revised approach adopted by the HRC (Keller \& Grover, 2012). The aim of the comparison is to draw a conclusion on whether the understanding of both international and constitutional courts differ from the understanding of the right to life presented in the General Comment no. 36. 


\section{NORMATIVE FRAMEWORK OF THE RIGHT TO LIFE}

Before focusing on the analysis of the duty to protect the right to life, it is worth recalling the main parts of legal definitions of the right to life in both international law and constitutions.

For the first time in international law, the right to life was defined in Article 3 of the Universal Declaration of Human Rights from 1948, in simple words - "everyone has the right to life".

The next definition, incorporated in the International Covenant for Civil and Political Rights, was drafted in more detailed fashion: "1. Every human being has the inherent right to life. This right shall be protected by law. No one shall be arbitrarily deprived of his life. 2. [...]". Covenant was later on supplemented with the Second Optional Protocol to the International Covenant on Civil and Political Rights, aiming at the abolition of the death penalty.

The right to life was defined at the regional level as well. The first international treaty that contained the definition of this right was the European Convention on the Protection of Human Rights and Fundamental Freedoms from 1950 (Article 2), supplemented with the Protocol No. 13 concerning the abolition of the death penalty in all circumstances. Other regions, in their respective international treaties defined this right in the American Convention on Human Rights, together with the Protocol to the American Convention on Human Rights to Abolish the Death Penalty, the African Charter on Human and People's Rights and the Arab Charter on Human Rights (Addo, 2010). The European Union solemnly proclaimed international legal document that defined inter alia the right to life - the Charter on Fundamental Rights of the European Union.

The European Convention on the Protection of Human Rights and Fundamental Freedoms defines it in Article 2: "1. Everyone's right to life shall be protected by law. No one shall be deprived of his life intentionally save in the execution of a sentence of a court following his conviction of a crime for which this penalty is provided by law. 2. [...]".

The American Convention on Human Rights in Article 4 states: "1. Every person has the right to have his life respected. This right shall be protected by law and, in general, from the moment of conception. No one shall be arbitrarily deprived of his life. 2. [...]".

The African Charter on Human and People's Rights in Article 4 states: "Human beings are inviolable. Every human being shall be entitled to respect for his life and the integrity of his person [...]".

The Arab Charter on Human Rights in Article 5 states: "Everyone has the right to life, liberty, and security of person; these rights are protected by law".

The Charter of Fundamental Rights of the European Union - Article 2: "1. Everyone has the right to life. 2. No one shall be condemned to the death penalty, or executed".

In addition to the mentioned legal acts, three specialised human rights treaties encompassed the right to life - the International Convention on the Protection of the Rights of All Migrant Workers and Members of Their Families, the Convention on the Rights of the Child and the Convention on the Rights of Persons with Disabilities.

The right to life is also protected within the international humanitarian law (Park, 2018) and international criminal law treaties, by stipulating prohibited acts (use of prohibited

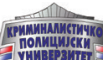


weapons resulting in death) within the Geneva Conventions, or in stipulating killing or a murder as actus reus of international crimes (Gowlland-Debbas, 2010; Quenivet, 2008).

Constitutions contain the right to life in similar, yet slightly different versions. The Constitution of the Republic of Serbia provides: "Human life is inviolable. There shall be no death penalty in the Republic of Serbia. Cloning of human beings shall be prohibited" (Article 24). The Constitution of the Republic of Croatia provides: "Each human being has the right to life. There shall be no capital punishment in the Republic of Croatia" (Article 21). The Constitution of the Republic of North Macedonia provides: "The human right to life is irrevocable. The death penalty shall not be imposed on any grounds whatsoever in the Republic of Macedonia" (Article 10). The Constitution of the Republic of Poland provides: "The Republic of Poland shall ensure the legal protection of the life of every human being" (Article 38). In the Basic Law of the Republic of Germany protection of the right to life is encompassed within the broader approach to personal freedoms: "Every person shall have the right to life and physical integrity. Freedom of the person shall be inviolable. These rights may be interfered with only pursuant to a law" (Article 2, paragraph 2). Slovakia's Constitution stipulates: "Everyone has the right to life. Human life is worthy of protection even before birth. 2. No person may be deprived of life. 3. The death penalty shall be inadmissible. 4. No infringement of rights shall occur if a person has been deprived of life as a result of an act not defined as unlawful" (Article 15). Hungarian Constitution provides protection of the right to life in the first paragraph of Article 54: "(1) In the Republic of Hungary everyone has the inherent right to life and to human dignity. No one shall be arbitrarily denied of these rights." The protection of the right to life, both international and national, is defined in broad terms, whether it is granted to a human life, every human being or everyone (Mathieu, 2006: 45). Meaning of words and phrases, as well as developing and discovering their substance is the task of bodies and courts authorised to protect the right and they provide it in the light of specific cases that they are deciding about. The main interpretation approach of the HRC adopted in the General Comment No. 36 is adopted in the light of the definition of Article 6 of the ICCPR. It is general and it does not rest on specific circumstances of a concrete case. The approach is defined at the very beginning of the General Comment (paragraph 3) in the following words: "The right to life is a right which should not be interpreted narrowly" (Šurlan, 2014).

The other governing remark adopted by the HRC, also general in its substance, is that the right to life is a "supreme" right, as stated in paragraph 2 of the General Comment No. 36, meaning that the right belongs to all human beings, no derogation is permitted even in times of armed conflicts, and it constitutes the fundamental right. Yet again, it is also underlined that the right to life is not absolute; there are rather situations when deprivation of liberty is permissible or even when the deprivation of the life is lawful. Interpretation aspect that also underlines the extensive interpretation approach is expressed in paragraph 7 in the following words: "States parties may be in violation of article 6 even if such threats and situations do not result in loss of life". Thus, the right to life does not apply only in situations when the loss of life occurs, but possibly in situations when the life is under threat. 


\section{THE DUTY TO PROTECT THE RIGHT TO LIFE}

Definitions cited in the previous part of this paper do not encompass the element of the duty to protect the right to life in clear and explicit words. Constitutions generally keep their definitions of the right to life in the broadest version. Approaches are that everyone or each human being has the right to life or that human life is inviolable. Definitions in several of the cited international acts, beside the general expression of the right to life, encompass two important elements: 1) prohibition of intentional or arbitrary deprivation of life, and 2) obligation to protect the life by law. These elements of the right to life form the ground for the conclusion that states do have the duty to protect the right to life. As much as it is quite easy to express that statement, it is as much difficult to define the scope and limits of this duty.

Part II of the General Comment no. 36 is dedicated to the most well-known aspect of the right to life - the prohibition against arbitrary deprivation of life (Quenivet, 2008). In Paragraph 1 of Article 6 of the International Covenant on Civil and Political Rights, it is prescribed that a life must be protected by law and that no one should be arbitrarily deprived of life. The HRC defines that deprivation of life is arbitrary if it is inconsistent with international law or domestic law. Yet again, not each and every deprivation of liberty that is grounded in the law is ipso facto non-arbitrary. Thus, notions "against the law" and "arbitrariness" are not equated. Behaviour that would not be labelled as arbitrary is defined in the very Comment, in usual examples, through paragraphs 10-17. In the most general words, this aspect of the right to life is a description of the prohibition of murder, in all of its possible versions. Deprivation of life, in its legal essence, has been defined within the criminal law as a crime of murder and criminal law has always been the main legal branch to protect the right to life (Tomuschat, 2010). In the words of the HRC: "20. States parties must enact a protective legal framework which includes effective criminal prohibitions on all manifestations of violence or incitement to violence that are likely to result in a deprivation of life, such as intentional and negligent homicide, unnecessary or disproportionate use of firearms, infanticide, "honour" killings, lynching, violent hate crimes, blood feuds, ritual killings, death threats, and terrorist attacks. The criminal sanctions attached to these crimes must be commensurate with their gravity, while remaining compatible with all provisions of the Covenant".

However, protection of the right to life, as the human right, extends to other legal branches, not only criminal law. The duty to protect the right to life is prescribed in the first paragraph of Article 6 of the International Covenant on Civil and Political Rights in the words that the right to life "shall be protected by law". This sentence, sounding very legalistic, is just an entering gate into the huge area of laws, creating variety of norms that should guard and save lives. In the words used by the HRC itself - "the duty to protect by law the right to life entails that any substantive ground for deprivation of life must be prescribed by law and defined with such precision to avoid overly broad or arbitrary interpretation or application" (paragraph 19).

The aspect of the duty to protect, well-known and already prescribed in all legal systems, rests in the field of a control of firearms, whether in the domain of possession or use of firearms. The aspect of firearms control comes in all of its forms - control for state organs, as well for individuals, criminals, terrorists, irregular armed groups, etc. State parties are 
obliged to "take adequate measures of protection, including continuous supervision, in order to prevent, investigate, punish and remedy arbitrary deprivation of life by private entities, such as private transportation companies, private hospitals and private security firms". This aspect of the duty to protect the right to life by the HRC is broadly extended, but only in the scope not in its nature (Joseph, 2019: 352).

Scrutinising the duty to protect the right to life, the HRC has also encompassed special measures of protection towards persons in situation of vulnerability, whose lives have been placed at particular risk because of specific threats or pre-existing patterns of violence (paragraph 23). There is quite a number of persons recognised by the HRC to be specifically vulnerable - officials fighting corruption and organised crime, witnesses to crime, victims of domestic and gender based violence and human trafficking, but also groups of persons such as - human rights defenders, journalists, prominent public figures, humanitarian workers, children, LGBT persons, persons with albinism, alleged witches. Duty concerning the right to life encompasses obligation for states to adopt special measures for protection of these individuals such as "the assignment of around-the-clock police protection, the issuance of protection and restraining orders against potential aggressors and in exceptional cases, and only with the free and informed consent of the threatened individual, protective custody". Thus, the duty to protect the right to life has, by the reasoning of the HRC, strong preventive character.

Obligation for states under the aspect of the duty to protect the right to life is specifically underlined in respect of persons with disabilities, either psychosocial or intellectual disabilities, also in terms of special measures that states should undertake to prevent harm, not only deprivation of life (paragraph 24). Preventive measures for this group encompass accommodation or prevention of unwarranted use of force by law enforcement agents. Specific position is also created toward persons deprived of their liberty, which is to say in states custody. This area nevertheless is not all new, covered as well with the prohibition of torture, but with such an interpretation complemented with the protection on the very life. Another specific aspect of the duty to protect concerns the obligation of states in respect of refugees and migrants, which is of specific importance in contemporary world. The duty to respect and ensure the right to life requires states to refrain from deporting, extraditing or transferring individuals to those states where their lives could be under risk. Approach to the protection of refugees and migrants, as formulated in the General Comment No. 36 is even broader from the scope of protection guaranteed to refugees in the very Convention on the status of refugees from 1951 and the concept of non refoulement (paragraph 31).

The most radical aspect and the extension that goes beyond the existing case law or usual understanding of the scope of the duty to protect the right to life is the aspect that concerns general conditions in society (Joseph, 2019: 358). This aspect is verbalised not as the previously discussed aspects, in terms of obligation, but in a rather softer manner as - should. Thus states "should take appropriate measures to address the general conditions in society that may give rise to direct threats to life or prevent individuals from enjoying their right to life with dignity" (paragraph 26).

The concept and the main ground for listing a number of general conditions rely on the potential to endanger life. These are, at the same time - criminal and gun violence, pervasive traffic, industrial accidents, degradation of environment, but also diseases such as AIDS, malaria, tuberculosis, substance abuse, hunger or even homelessness. In those as- 
pects of general living conditions the HRC found that states should take all measures that can ensure access to essential good, food, water, shelter, health care, fire fighters, ambulance, police forces, social housing programs.

The HRC has already been in the situation to apply its General Comment No. 36 within specific case brought before it, in the case Portillo Cáceres $v$. Paraguay that was decided at July 2019 (UNHRC, 2019). The circumstances of the case - death of peasants after poisoning by high amounts of pesticide and insecticides used at industrial farms, raised the question on the duty of a state to protect the right to life conducting the environmental protection. The HRC stressed: "7.3. [...] The Committee recalls its General Comment No. 36, in which it has established that the right to life also concerns the entitlement of individuals to enjoy a life with dignity and to be free from acts or omissions that would cause their unnatural or premature death. States parties should take all appropriate measures to address the general conditions in society that may give rise to threats to the right to life or prevent individuals from enjoying their right to life with dignity, and these conditions include environmental pollution. [...] Furthermore, the Committee recalls that States parties may be in violation of Article 6 of the Covenant even if such threats and situations do not result in loss of life.

7.4 The Committee also takes note of developments in other international tribunals that have recognized the existence of an undeniable link between the protection of the environment and the realization of human rights and that have established that environmental degradation can adversely affect the effective enjoyment of the right to life. Thus, severe environmental degradation has given rise to findings of a violation of the right to life."

This decision is grounded on the new reading of the right to life as expressed in paragraphs 26 and 62 of the General Comment No. 36: "The duty to protect life also implies that States parties should take appropriate measures to address the general conditions in society that may give rise to direct threats to life or prevent individuals from enjoying their right to life with dignity. These general conditions may include [...] degradation of the environment $[\ldots]$ " (paragraph 26). Thus, it can be concluded that this decision has affirmed the duty to protect the environment in order to comply with the right to life.

In its Views the HRC has relied on the jurisprudence of the ECHR, citing in concrete cases Öneryildiz v. Turkey, Budayeva and Others v. Russia, and Özel and Others v. Turkey. The European Court of Human Rights has already developed the extensive approach towards the duty to protect the right to life. In the case of Özel and Others $v$. Turkey which tackled a natural disaster, the Court extensively opted for the duty for states to "[...] safeguard the lives of those within their jurisdiction. That obligation must be construed as applying in the context of any activity, whether public or not, in which the right to life may be at stake, but it also applies where the right to life is threatened by a natural disaster"(European Court of Human Rights [ECHR], 2015) .

Another good example to compare the reasoning of the ECHR and the HRC could be the latest ECHR judgment in the case N. A. v. Finland. The ECHR has found the violation of the right to life, i.e. Article 2 of the European Convention on Human Rights and Fundamental Freedoms, as well as violation of torture, as stipulated in Article 3 of the mentioned convention. The reasoning of the Court is built on the duty to protect the aspect of the right to life, specifically concerning an asylum-seeker. Factual ground of the case - an Iraqi who fled from his native country, in fear of death, was annulled an asylum status in 
Finland and forced to go back to Iraq; subsequently he was killed. The ECHR has found that the assessment of the Finnish authorities had failed to comply with the guarantees of Article 2 (ECHR, 2019). In other words, Finland did not apply the aspect of the right to life consisting in the duty to protect. This case is the excellent example of the conjunction of the ECHR reasoning with the reasoning of the HRC expressed in paragraph 31 of the General Comment No. 36, concerning specific duties towards refugees and migrants - "31. The obligation not to extradite, deport or otherwise transfer pursuant to Article 6 of the Covenant may be broader than the scope of the principle of non refoulement under international refugee law, since it may also require the protection of aliens not entitled to refugee status. States parties must, however, allow all asylum seekers claiming a real risk of a violation of their right to life in the State of origin access to refugee or other individualized or group status determination procedures that could offer them protection against refoulement". It should be underlined that such an extensive approach towards the duty to protect the right to life belongs to the new reading of the right to life. In older cases the HRC reasoned more restrictively exactly in cases of deportation towards the duty to protect the right to life. In the case G.T. v. Australia from 1997 the HRC found that deportation cannot be considered in terms of the right to life in the respective case (UNHRC, 1997), but in the next cases that stand was revised into the duty to consider a deportation as an aspect that can be connected to the duty to protect the right to life (UNHRC, 2003; UNHRC, 2015a; UNHRC, 2015b).

When speaking about the duty to protect, it is important to differentiate between abstract duty to protect the right to life from concrete preventive duty to protect the right to life that is imposed on states. Thus, there are duty to protect the right to life by law and duty to protect the right to life by undertaking the appropriate preventive measures. The duty to protect the right to life is to be achieved primarily through legal acts. If the laws are drafted in terms of the duty to protect the right to life, the preventive effect of the right to life would be highly achieved. Preventive potential is stronger in the abstract duty to protect and it should be differentiated from the positive obligations to undertake concrete actions in specific situations.

The aspect of the duty to protect the right to life through preventive measures has been cleared in the ECHR jurisprudence, with its strong influence on the reasoning of constitutional courts (Constitutional Court of the Republic of Serbia [CCRS], 2016; Constitutional Court of the Republic of Montenegro [CCRM], 2017; Constitutional Court of the Republic of Croatia [CCRC], 2018; CCRC, 2019). In one of its cases the Constitutional Court of the Republic of Croatia has been deliberating on the duty to protect the right to life in terms of police forces action, following the reasoning of the ECHR expressed in the case Bljakaj and others v. Croatia (CCRC, 2018). In the specific judgment the ECHR stated its well established understanding that according to the right to life states are obliged not only to refrain from the intentional and unlawful taking of life, but there is obligation to undertake the appropriate steps to safeguard the lives within their jurisdiction (ECHR, 2014). Deliberating further on the obligation of the law enforcement machinery to protect individuals whose lives are in danger, the ECHR took a stand that the duty to protect, i.e. positive obligation to prevent deprivation of life should not be interpreted in a way to "impose an impossible or disproportionate burden on the authorities, bearing in mind the difficulties involved in policing modern societies, the unpredictability of human conduct and 
the operational choices which must be made in terms of priorities and resources" (Ibid., $\$$ 105). The ECHR has drawn the line between the situation that arises positive obligation that could be encountered as the guarantee of the right to life and the situation not arising the duty to protect the right to life. In the very words of the ECHR: "Accordingly, not every claimed risk to life can entail for the authorities a Convention requirement to take operational measures to prevent that risk from materialising. A positive obligation will arise, the Court has held, where it has been established that the authorities knew or ought to have known at the time of the existence of a real and immediate risk to the life of an identified individual or individuals from the criminal acts of a third party, and that they failed to take measures within the scope of their powers which, judged reasonably, might have been expected to avoid that risk" (Ibid., \$106).

The Constitutional Court of the Republic of Croatia followed the expressed reasoning of the ECHR and formulated three groups of obligations imposed by the right to life on a state: "These are a negative obligation on the state to refrain from the illegal deprivation of life, a positive obligation on the state to enact effective normative and enforcement measures to prevent loss of life when avoidable, and a procedural obligation on the state to investigate suspected deaths" (CCRC, 2019).

Almost identical approach has been taken by the Constitutional Court of the Republic of Montenegro. Deliberating on the characteristics of the right to life the Court has expressed: "The obligations of the state can be classified into three groups: the obligation to refrain from the illegal deprivation of life - a negative obligation; the obligation to adopt effective norms and implementing measures as well as to take other practical steps to protect life the material aspect; obligation to investigate deaths - procedural obligations" (CCRM, 2017).

The Constitutional Court of the Republic of Serbia has developed two-fold approach towards the right to life (CCRS, 2013): 1) material aspect of the right to life encompasses the obligation for a state to prevent deprivation of life (CCRS, 2011; CCRS, 2017b) and 2) procedural aspect encompasses the obligation to undertake an impartial and effective investigation (CCRS, 2015; CCRS, 2017a). The first aspect is understood broadly as well as the obligation of undertaking preventive measures for life protection, especially in the field of activities that present risk to life.

The Constitutional Court of the Republic of Serbia also relied on the ECHR jurisprudence and expressed respect to the stands developed in the ECHR jurisprudence, in its decisions concerning the right to life. In its decisions, the Court invoked specific reasoning by the ECHR expressed in its Judgment in the case Mladenovic v. Serbia (CCRS, 2013; CCRS, 2016). The ECHR stressed primarily the obligation to protect life, but also that an investigation must be effective "in the sense that it is capable of leading to the identification and punishment of those responsible" and that this specific obligation is "not an obligation of result, but of means" (ECHR, 2012).

Summarising the expressed reasoning of the courts, it is important to bear in mind the potential of specific decision or judgment to express general stands. Each decision is conducted by specific set of facts and as such, it has lesser potential to provide general scope of any right. However, each decision is important part of the broader approach and it presents general direction of reasoning. On the other hand, the approach of a general comment is abstract, general, and its task is to determine direction to be applied in specific cases. Jurisprudence shows the knowledge of the general direction of reasoning, but it is 
hard to determine in one firm conclusion that all aspects of the duty to protect the right to life will be implemented, as expressed in General Comment No. 36.

The comparison of the presented approaches by various bodies shows that the concept of the duty to protect the right to life is overwhelmingly accepted. While the HRC uses the phrase - the duty to protect, the ECHR and constitutional courts use the phrase - positive obligations of a state, substantive and procedural (Šurlan, 2011: 102). The meaning of both phrases is the same. The difference between them does not lie in wording, but in the experience of applying this approach, and judging by applying this approach.

\section{CONCLUSION}

The duty to protect the right to life undoubtedly is the element of the right to life. It has been primarily confirmed in the jurisprudence of the ECHR from the very first decision concerning this right, in the expression of the positive obligation of a state. It has also been confirmed by constitutional courts through the application and interpretation of the right to life as defined in respective constitutions. At the present moment though, the scope of the duty to protect the right to life has been broadened by the reasoning of the HRC presented in the General Comment No. 36. One aspect of the duty to protect the life is enshrined in stressing the obligation for states to adopt relevant laws. The other aspect of the duty is to adopt and apply preventive measures in all aspects of social life with the aim to prevent the loss of lives. As much as the present jurisprudence of the ECHR and constitutional courts accepts the existence of the duty to protect the right to life, it is difficult to define the scope and limits of this duty. The HRC has set a goal very high. The achievement of this high goal is now to be tested through specific cases that are going to be deliberated before courts and bodies. For these final remarks, nevertheless, it should as well be mentioned that general comment itself is not a binding legal document, but only the mean of interpretation of a specific right. It is thus on respective courts and relevant bodies to decide on the implementation of the recommended interpretation of the right to life.

\section{REFERENCES}

Addo, M. K. (2010). The legal nature of international human rights. Martinus Nijhoff Publishers.

Constitutional Court of the Republic of Croatia (CCRC), U-III-2733/2017, Decision of November 14, 2018.

Constitutional Court of the Republic of Croatia (CCRC), U-IIIBi-863/2019, Decision of July 9, 2019.

Constitutional Court of the Republic of Montenegro (CCRM), U-III broj 6-16, Decision of November 29, 2017.

Constitutional Court of the Republic of Serbia (CCRS), UZ-4077/2010, Decision of July 14, 2011. 
Constitutional Court of the Republic of Serbia (CCRS), UZ-4527/2011, Decision of January 31, 2013.

Constitutional Court of the Republic of Serbia (CCRS), UZ-10066/2012, Decision of October 8, 2015.

Constitutional Court of the Republic of Serbia (CCRS), UZ-356/2015, Decision of December 8, 2016.

Constitutional Court of the Republic of Serbia (CCRS), UZ-4473/2014, Decision of March 9, 2017(a).

Constitutional Court of the Republic of Serbia (CCRS), UZ-6813/2014, Decision of October 26, 2017(b).

Gowlland-Debbas, V. (2010). The right to life and the relationship between human rights law and humanitarian law. In C. Tomuschat, E. Lagrange \& S. Oeter (Eds.), Right to life (pp. 123-150). Martinus Nijhoff Publishers.

European Court of Human Rights (ECHR), Mladenovic v. Serbia, Application no. 1099/08, Judgment of May 22, 2012.

European Court of Human Rights (ECHR), Bljakaj and others v. Croatia, Application no. 74448/12, Judgement of September 18, 2014.

European Court of Human Rights (ECHR), Özel and Others v. Turkey, Applications nos. 14350/05, 15245/05 and 16051/05), Judgment of November 17, 2015.

European Court of Human Rights (ECHR), N.A. v. Finland, Application no. 25244/18, Judgment of November 14, 2019.

Joseph, S. (2019). Extending the right to life under the International Covenant on Civil and Political Rights: General Comment 36. Human Rights Law Review, 19(2), 347-368.

Kalin, W., \& Kunzlin, J. (2019). The law of international human rights protection. Oxford University Press.

Keller, H., \& Grover, L. (2012). General Comments of the Human Rights Committee and their legitimacy. In H. Keller \& G. Ulfstein (Eds.), UN Human Rights Treaty bodies: Law and legitimacy (pp. 116-198). Cambridge University Press.

Mathieu, B. (2006). The right to life in European constitutional and international case-law. Council of Europe Publishing.

Park, I. (2018). The right to life in armed conflict. Oxford University Press.

Quenivet, N. (2008). The right to life in international humanitarian law and human rights law. In R. Arnold \& N. Quenivet (Eds.), International humanitarian law and human rights law: Towards a new merger in international law (pp. 331-354). Martinus Nijhoff Publishers.

Šurlan, T. (2011). Pravo na život u jurisprudenciji Evropskog suda za ljudska prava. In Ž. Nikač (Ed.), Policija u funkciji zaštite ljudskih prava: tematski zbornik radova (pp. 99-113). Kriminalističko-policijska akademija.

Šurlan, T. (2014). Univerzalna međunarodna ljudska prava: mehanizmi zaštite. Kriminalističko-policijska akademija. 
Tomuschat, C. (2010). The right to life: Legal and political foundations. In C. Tomuschat, E. Lagrange \& S. Oeter (Eds.), Right to life (pp. 3-20). Martinus Nijhoff Publishers.

UN Human Rights Committee (UNHRC), CCPR General Comment No. 6: Article 6 (Right to Life), 30 April 1982.

UN Human Rights Committee (UNHRC), CCPR General Comment No. 14: Article 6 (Right to Life) Nuclear Weapons and the Right to Life, 9 November 1984.

UN Human Rights Committee (UNHRC), G.T. v. Australia, CCPR/C/61/D/706/1996, 4 December 1997.

UN Human Rights Committee (UNHRC), Roger Judge v. Canada, CCPR/ C/78/D/829/1998, 13 August 2003.

UN Human Rights Committee (UNHRC), A.H. v. Denmark, CCPR/C/114/D/2370/2014, 7 September 2015(a).

UN Human Rights Committee (UNHRC), Osayi Omo-Amenaghawon v. Denmark, CCPR/ C/114/D/2288/2013, 15 September 2015(b).

UN Human Rights Committee (UNHRC), CCPR General Comment No. 36 (2018) on Article 6 of the International Covenant on Civil and Political Rights, on the right to life, CCPR/C/ GC/36, 30 October 2018.

UN Human Rights Committee (UNHRC), Views adopted by the Committee under Article 5 (4) of the Optional Protocol, concerning communication No. 2751/2016, 25 July 2019. 